\title{
Import, Export and Economic Growth: the Case of Lower Income Country
}

\author{
Helal Uddin ${ }^{1}$ and Mst. JamiaJannat Khanam ${ }^{2}$ \\ ${ }^{1}$ Doctoral Student, Asia Pacific Studies, Ritsumeikan Asia Pacific University, Japan. \\ ${ }^{2}$ Senior Teacher, South Point School, and College, Dhaka, Bangladesh.
}

\begin{abstract}
Bangladesh is now considered as a lower middle-incomecountry by the blessing of international trade.Therefore, Bangladesh needs to take an effective policymaking decision in terms of international trade fortheirfurther development. Hence it is important to check whether Bangladesh needs more import or export for its further development. As a result, current research tries to see the relationship between import and GDP growth of Bangladesh by taking 32 years (1981-1992) of time series data.Relevant data were collected from the Bangladesh Bank website and World Bank Database. From the analysis, theresearcherconcludes that import is negatively related with GPD growth as well as GDP growth rate is also negatively related with Import.
\end{abstract}

Keywords: Import, Export, GDP growth, Inflation, Bangladesh

\section{Introduction}

Why some countries are poor and some are rich? It's not a new rather an old question in the economic literature. Different economics school provides adifferent opinion. Based on classical economic school, Population or Human Capital is the primary factors for economic development. When countries population increases the Gross domestic product (GDP) also increases, but this school also arguedthat this increased population had an adverse impact on GDP growth which decreases the GDP. According to Neoclassical economics school,Human capital or capital is not only the factors that increase the GDP but also other factors too. They find that capital contributes only one-eighth of the GDP but rest are contributed by technology. When countries become technically rich they become rich easily. All school like Classical and Neoclassical schools focuses on the supply side of the GDP. But Keynesian Economics of Schooldoesn't believe that supply side had too much impact onGDP growth rather demand side. According to Keynesian economics,changes in demand side will directly impact on GDP. For example Consumption, Investment, Government expenditure, and Net Export which has a direct impact on GDP and among them all variables Government Expenditure is the easiest one.

GDP is the monetary value or market value of all final goods and services produced in a country over a period of a year (Van den Bergh, 2009, p. 117). GDP is the primary indicator to measure a country's economic status. Without GDP, it's difficult to measure the size of the economy and living standard of any economy; higher the GDP, higher the living standard. As a result, all countries leaders try to increase their GDP as much as possible. There are numbers of ways to increase the GDP, among them the export is the easiest one next to Government Expenditure. Recall to the general formula of calculating Gross Domestic Product,

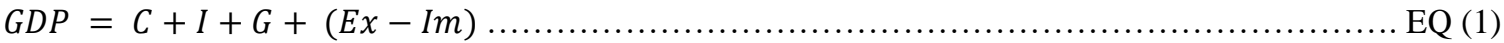

Where, $C=$ Consumption of all citizen, $I=$ Investment, $G=$ Government Expenditure, $E x=$ Total Export and $I m=$ Total Import. The equation (1) it is shown that the import is subtracted from GDP calculation, therefore, ahigh volume of import can reduce the GDP. As it is mention that all countries try to increase their GDP and the easiest way to increase GDP by increasing export or reducing import, but it's not possible to all countries at a time because if one country export, another country must import. If one country's balance of payment is positive, another country's balance of payment should be negative.

Although the above argument shows that the import has a negative relationship but some empirical studies found that the import has a positive relation with GDP. In this line, Zaheeret, al., (2014) and Awokuse (2007) on the other hand Esfahani, (1991) finds anegative relation with GDP.

The contribution of import on GDP is not a direct; it may have a positive relation with GDP like Lee's (1995) argument, Lee (1995) mentions that import can contribute to establishing and expand industrial sectors. Because new technology works as influencing factors to introduce the new industry. On the other side, some import goods especially the technology and machinery goods which improve the productivity of the economy. Therefore this may help to improve the economic growth. Amiti and Konings (2007) and Grossman and Helpman (1991) mention that, whenthe economy has an access on high-quality intermediate goods at a cheaper price from theforeign market, it's better to import from a foreigncountry that will improve the quality of life. On the other hand import medical goods which extend the life expectancy of the country. As a result, more workforces can able to work and it increases the output which finally improves the GDP growth. From this 
analytical framework, we can sense import has not directly but indirect impact on GDP growth. Therefore proposed research try to gather more evidence based on Bangladesh whethertheimport is positively or negatively related to GDP growth and vice-versa.

\section{Objective of the research}

From the above discussion we see,there is both positive and negative relationship between import and economic growth.But no direct answer whether the relation is positive or negative. Therefore, the proposed research is to gather more evidence based on Bangladesh byexploring the following points 1) Export-import scenario of Bangladesh. 2) The causality between import and GDP growth; 3) Import influence GDP growth or GDP growth influence import?

\section{Significant of the research}

According to World Bank report on July 1, 2015; Bangladesh, Kenya, Myanmar, and Tajikistan are no more lower-income countries, nowtheymoved a little bit ahead of economic development from lower income countries to lower-middle income countries (World Bank, 2015). Therefore, all lower middle-income countries have to take effective policies that willadvance their economy. As a result,policymakershave to find sufficient evidence that will facilitate them whether they will restrict import which in theoretically have a direct negative impact on economic growth or whether import which has an indirect positive impact on GDP growth.

This paper is organized in the following order. Section 2 will discuss Bangladesh economic scenario. Section 3 will discuss literature review. Section 4 will discuss hypothesis and methodology. Section 5 will provide empirical results and finally concludes with section 6 .

\section{Bangladesh Export-Import Scenario}

Bangladesh is a South Asian developing country with a landmass of 147,570 square kilometers. Before 1947 Bangladesh, India, and Pakistan was one country named as British India. In 1947 India and Pakistan divided based on religious. India is declared as a Hindu majority country and West Pakistan (currently Pakistan) and East Pakistan (Currently Bangladesh) are Muslim majority country. On December 16, 1971, East Pakistan got independent from West Pakistan and became a newly independent country named "Bangladesh" (Official name is People's Republic of Bangladesh). Bangladesh is a Muslim majority (about 89.7\%) country, but it has a significant percentage of Hinduism (9.2\%), and other religious like Buddhists (0.7\%), Christians (0.3\%), and Animists $(0.1 \%)$.

Bangladesh is the eighth densely populated country in the world with 1,188 people per square kilometer (WB, 2013) and according to World Bank report, GDP per capital is $\$ 822.2$ in 2012. Bangladesh is categories as a lower middle-income country by 2015 (World Bank, 2015). Current GDP growth rate is nearly $6 \%$ per year. According to Index Mundi (n.d), there are three main sectors that comprise Bangladesh GDP; Agriculture (16\%); Industry (30.4\%); and Service (53.6\%; 2015 est.).

Bangladesh has a strong network with another world in terms of import and export. Based on World Integrated Trade Solution (WITS), Bangladesh has an export partner of 188 partners where they export 1768 product and also has a strong import relationwith 183 partners where they import 4184 items of products. Top five export countries are United State (21.00\%); Germany (15.55\%); United Kingdom (9.49\%) France (6.42\%) and Spain $(4.41 \%)$ and top five imported countries are Thailand (22.78\%); India (11.23\%); China (8.76\%); Indonesia (5.97\%) and Singapore (5.16\%)According to Akhter (2015) Bangladesh export industry can be divided into two groups, traditional exports goods (Raw jute, tea, leather, paper, newsprint, naphtha, furnace oil and bitumen, agriculture products etc.) and nontraditional exports goods (Readymade garments, frozen foods, fruits and vegetables, handicrafts, fertilizer and chemical products, leather shoes, ceramic goods etc.). Initially, main export goods were traditional exports goods but latterly they mostly depend on non-traditional export items. The export earnings were 8655 US dollar in 2004-05, it has increased to 16597 US dollar in 2009-10 and it was 27027 US dollar in 2012-13 which was highest earnings.Bangladesh is not self-sufficient in terms of food, energy, and industrial goods. Therefore Bangladesh always has a trade deficit with international parties. Bangladesh imported goods can be categories into main four groups; Main primary goods (Rice, Wheat, Oil Seeds, Crude petroleum, and Cotton); Main manufactured goods (Edible oil, Petroleum goods, Fertilizer, Clinker, Staple Fiber and Cotton); Capital Instrument and Others Goods.

\section{Literature Review}

In the literature, there has been ample study done to see the relationship between export, import and GDP growth. The literature can be divided into three categories. The first categories which focuses only on the export and economic growth like Dawson and Hubbard (2004); Kavoussi (1984); Feder (1983); Tyler (1981); Balassa (1978); Heller and Porter (1978); and Michaely (1977) on the other side, researcher focuses only on import and economic development like Zaheer et, al., (2014) and Esfahani, (1991), the another categories of the literature analysis the relationship both export and import on GDP growth like Awokuse (2007) and Chen and 
Dong (2012).Dawson and Hubbard (2004) see the relationship between export and economic growth taking 14 Central and East European countries duringthetransition assimple; using panel data over a period of 6 years (1994-1999). Finally, they conclude that export has a positive and significant relationship with economic growth.Chen and Dong (2012) the relationship between capital stock, labor capital, export trade and import trade with GDP. They used panel data of 31 provinces, municipalities and autonomous regions in China for a period of 12 years from 1997 to 2008; by using Pointwise Regression Estimation they conclude that all independent variables are positively related to economic growth and the relationship is statistically significant.Awokuse (2007) examines the causal relationship between trade (both export and import) and economic growth for Bulgaria, Czech Republic, and Poland. Data from International Monetary Fund (IMF) database for the period of 1994:1 2004:3 (for Bulgaria), 1993:1 2002:4 (for Czech Republic), and 1995:1 2004:2 (for Poland) using correlation matrix. They find that for all three countries, both export and import are positively related with GDP.

On the other hand impact of import on economic development remains an interesting topic in the economic literature (Bhatti\& Bashir, 2015, p35). Some argued that the import is positively related with GDP like Schneider, (2005); Zaheeret, al., (2014); Awokuse(2007) and some argue that its negatively related with GDP growth like Tahir et, al., (2015) and Esfahani, (1991).Schneider, (2005) examines the role of hightechnology trade in determining a country's rate of economic growth using a unique panel data set of 47 developed and developing countries over a period of 21 years(1970 to 1990). Foreign technology has a stronger positive impact on per capita GDP growth. Which means the technology import from theforeign country can lead economic growth. Zaheeret, al., (2014) conduct a research to find the impact of import on GDP growth in Pakistan by taking 10 years import and export data. They conclude that there has a positive and direct impact of import on GDP growth of Pakistan.Tahiret, al., (2015) analyses the external determinants and economic growth of Pakistan using time series econometric techniques; data coverage for the period of 1977-2013. They use foreign remittances, foreign direct investment, and foreign imports asaproxy of external determinants. Their empirical result suggests that both foreign remittances, and foreign direct investment have a positive impact on economic growth and imports have an adverse impact.

Inthecase of Bangladesh, not too much research done to see the relationship between Import and GDP growth. Ahmed and Uddin, (2009) investigates the causally between export and GDP growth of Bangladesh taking import, remittance as a control variable; using annual data from 1976 to 2005. Theyfind limited support in favor of export-led growth hypothesis and for imports, remittance and GDP the relationship is unidirectional. Akhter (2015) investigate the relationship between import, export and GDP growth. They conclude that the impact of exports on economic growth is positive and an opposite scenario is found in the case of import.All these researchinvestigated the relationship between export,import, and GDP growth by taking of different control variables like import and remittance. But no evidence found in the literature that considered government expenditure and inflation which is the key elements of GDP. Therefore current research is going to provide further evidence about the relationship between import and GDP growth and other variables like Government expenditure and inflation. That will provide a new window in the literate for further debate.

\section{Methodology}

The discussion in the research has followed qualitative approaches to achieve the identified objectives. This section lays out the data, variables, and model through which the paper wants to accept or reject our hypotheses.

\section{Hypothesis}

As mentioned before the formula of calculating Gross Domestic Product is-

$$
G D P=C+I+G+(E x-I m)
$$

Where, $C=$ Consumption of all citizen, $I=$ Investment, $G=$ Government Investment, $E x=$ Total Export and $I m=$ Total Import. The equation (1) it is shown that the import is subtracted from GDP calculation there forahigh volume of import can reduce the GDP. From this viewpoint, we can sense our null hypothesis-"Import is negatively related with GDP and vice-versa".

\section{Model Specification}

As it is mention that this research is going to analysis the relationship between import and GDP growth of the country and vice-versa. To analysis, the relationship researcher develop a model

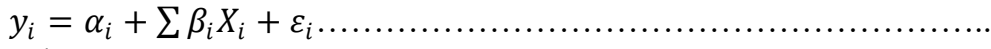

Where,

$$
\begin{aligned}
& y_{i}=\text { DependentVariable } \\
& \alpha_{i}=\text { InterceptoftheEquation } \\
& \beta_{i}=\text { coefficientof } X_{i} \text { varables } \\
& X_{i}=\text { DifferentIndependentvariables } \\
& \varepsilon_{i}=\text { errorterms }
\end{aligned}
$$


Calibration of our variables into the model yields the following equation:

$G D P_{i}=\alpha_{i}+\beta_{1} E_{X X O R T_{i j}}+\beta_{2} I M P O R T_{i}+\beta_{3} G$ IVV $_{i}+\beta_{4} I N F_{i}+\varepsilon_{i}$

IMPORT $_{i}=\alpha_{i}+\beta_{1} G D P_{i j}+\beta_{2} E_{\text {XPORT }}+\beta_{3} G \mathrm{CV}_{i}+\beta_{4} I N F_{i}+\varepsilon_{i} \ldots \ldots \ldots \ldots \ldots \ldots \ldots . . . \ldots \ldots$

Where,

$G D P=G D P$ growth rate of country $i$

EXPORT = Real Export by country $i$

$I M P O R T=$ Real import by country $i$

$G O V=$ Government Expenditure by country $i$

$I N F=$ Inflation of Country $i$

The EQ (3) provide us the relationship of import on GDP growth, and EQ (4) give the result of the relationship of GDP growth on Import. In EQ (3) GDP represent as a dependent and Import as an Independent,wherein EQ (4) import as a dependent and GDP growth rate is an independent variable; other variables like Export, Government Expenditure, and Inflation rate works as control variables.

\section{Sampling and Data Collection}

For the proposed research researcher take Bangladesh as a Sample country. Bangladesh is no more a lower income country rather it achieve is income growth. Now Bangladesh is considered as a lower middleincome country. This motivates the researcher to take Bangladesh as a sample country. The required data is collected from Bangladesh Bank and World Bank database. Bangladesh starts international trade liberalization in 1980, therefore,this research covers from 1981 to 2012(Constant 2005) except inflation. Time series properties of the data are examined using unit root tests. The Augmented Dickey-Fuller (ADF) test for the null hypothesis of non-stationarity was used to see the unit root among variables. Table 1 shown the unit root test result.

Table 1:Augmented Dickey-Fuller (ADF) Unit Root Test

\begin{tabular}{|c|c|c|}
\hline & Test Statistic & $\begin{array}{c}\text { MacKinnon approximate } \\
\text { p-value }\end{array}$ \\
\hline GDP & -4.330 & 0.0004 \\
\hline Export & -3.341 & 0.0131 \\
\hline Import & -2.870 & 0.0490 \\
\hline Govt. Exp. & -2.924 & 0.0427 \\
\hline Inflation & -3.323 & 0.0139 \\
\hline
\end{tabular}

\section{Results}

Figure 1 shows the export-import trend from 1981 to 2012. From this figure, we see thatthere is always a trade deficit in Bangladesh. It indicates that Bangladesh imports more than its export. Both export import has a slower growth from 1981 to 1991, then from 1992 to 2010 moderate growth and from 2011onword both export and import sharply increases.

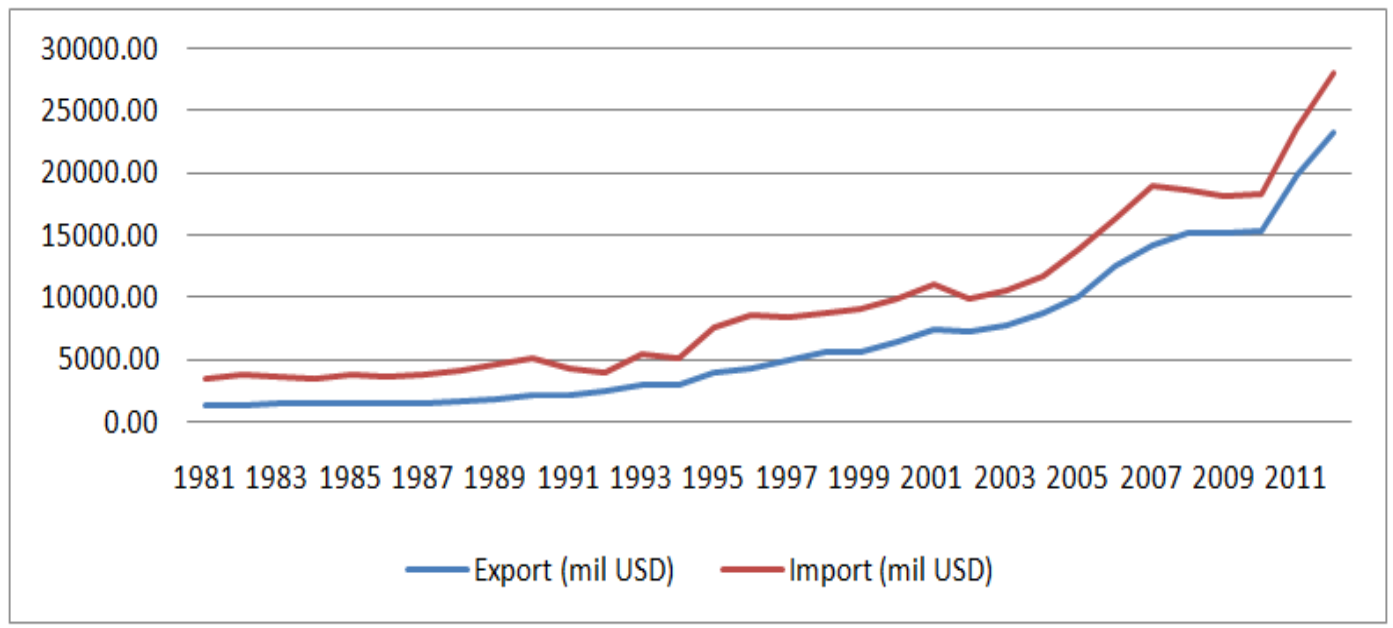

Figure 1: Export and Import Scenario of Bangladesh

Figure 2 shows the real GDP of Bangladesh In 1981, the GDP was $\$ 20853.06$ million and in 2000, it was $\$ 46268.66$ million. The growth was constant, and in 2006, the amount reached to $\$ 64273.56$ million. Finally, in 2012 it became $\$ 92429.55$ million. 


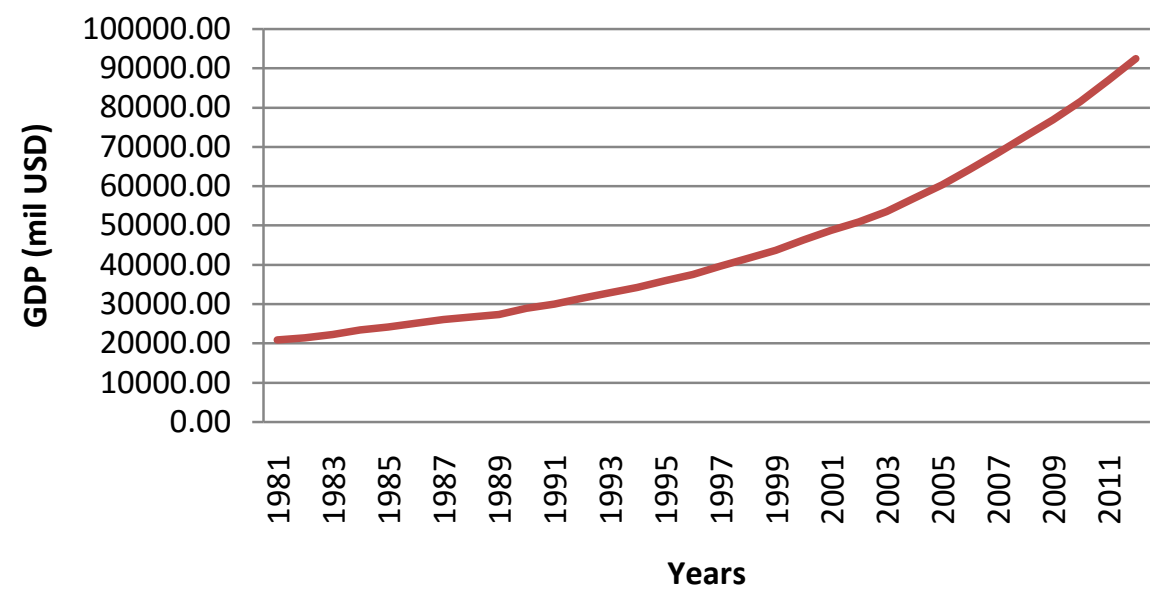

Figure 2: GDP of Bangladesh (Constant 2005)

Table 1,shows the casualty of both imports is related with GDP and GDP is related toimporting. Inthe first case, we see that Import is negatively related with GDP which supports our hypothesis but the relationship is not statistically significant. The same conclusion also draws byTahiret, al., (2015), and Esfahani, (1991). Other control variables, such as Export is positively related with GDP and significant at 1\% level; which supports the traditional GDP calculation method where Export increases GDP growth. The same result also found by Chen and Dong (2012). Government expenditure is also positively related to GDP and significant at $1 \%$ level. The relationship between inflation and GDP is positive but not significant.

On the other side, the relationship between Export and GDP is negative which is expected because; from EQ (1) we see that the relationship should be negative but the concern that the relationship is not significant. Export is positively related to import, significant at $1 \%$ level as expected. Government expenditure is negatively related with Export at significant at $10 \%$ level. This means when government expenditure increases Import decreases. This mayberesults of,the government iscareful in theirexpenditure when government expenses they try to use their local product which decreases import. Inflation is positively related to import and significant at $1 \%$ level. This result is unexpected because in the traditional way when inflation increases export increases but import decreases.

Table 1: Econometric results

\begin{tabular}{|c|c|c|}
\hline Variables & GDP & EXPORT \\
\hline \multirow{2}{*}{ GDP } & & -0.1661532 \\
& & $0.3163919)$ \\
\hline \multirow{2}{*}{ EXPORT } & $0.3743712^{*}$ & $0.9766331^{*}$ \\
& $(0.12039944)$ & $(0.1357335)$ \\
\hline \multirow{2}{*}{ IMPORT } & -0.0608529 & \\
& $(0.1158771)$ & $-0.3179945^{* * *}$ \\
& $0.2519494^{*}$ & $(0.1747143)$ \\
\hline \multirow{2}{*}{ GOVT. EXP } & $(0.1009965)$ & $0.0160793^{*}$ \\
& 0.002629 & $(0.0045745)$ \\
\hline \multirow{2}{*}{ INFLATION } & $(0.0033038)$ & $4.794855^{*}$ \\
& $6.107161^{*}$ & $(1.902507)$ \\
\hline \multirow{2}{*}{ CONS } & $(0.5060745)$ & 0.8113 \\
\hline R-square & 0.64480 & 32 \\
\hline observation & 32 & Stand \\
\hline
\end{tabular}

$*, * *, * * *$ indicate significant at 1\%,5\%, and 10\% level respectively. Standard errors are given in the parenthesis.

\section{Conclusion and Recommendation}

This paper researcher tries to see the relationship between Export and GDP growth of Bangladesh by taking 32 years (1981-2012) data. Researcher finds that in all the sample years' export is less than import that means always there is a trade deficit. And from the analysis researcher finds that import is negatively related with Bangladesh GDP growth. Also, it is found that the relationship is not significant. The same result also finds by Tahiret, al., (2015), and Esfahani, (1991).As import is more than export and import is negatively related, so as a developing country, Bangladesh policymaker needs to take amorecareful decision about the internationaltradedecision when it comes to the GDP growth. On the other hand, the policymaker may encourage business people to establish new industry and produce alocal product which is imported in huge 
volume. This paper only considers Bangladesh which represents a lower middle-income country but this paper can't able to generalize this result is appropriate for all lower middle-income countries. This limitation maybe covered in our future research.

\section{Reference}

[1]. Ahmed, H. A., \&Uddin, M. G. S. (2009). Export, imports, remittance and growth in Bangladesh: An empirical analysis. Trade and Development review, 2(2), 79-92.

[2]. Akhter, M, (2015). The Impact of Export and Import on Economic Growth in Bangladesh. World Vision, 9(1), 66-81.

[3]. Amiti, M., Konings, J., (2007). Trade liberalization, intermediate inputs, and productivity: evidence from Indonesia. The American Economic Review 97 (5), 1611-1638.

[4]. Awokuse, T. O. (2007). Causality between exports, imports, and economic growth: Evidence from transition

[5]. Balassa B (1978) Exports and economic growth: further evidence. J Dev Econ 5:181-189

[6]. Chen, J., \& Dong, B. (2012).A nonparametric estimation on the effects of import and export trade to economic growth in China.Procedia Engineering, 29, 952-956.

[7]. Dawson, P. J., \& Hubbard, L. J. (2004).Exports and economic growth in Central and East European countries during transition. Applied Economics, 36(16), 1819-1824.

[8]. Feder G (1983) On exports and economic growth. J Dev Econ 12:59-73

[9]. Heller PS, Porter RC (1978) Exports and growth: an empirical re-investigation. J Dev Econ 5:191-193

[10]. Herrerias, M. J., \& Orts, V. (2011). Imports and growth in China.Economic Modelling, 28(6), 2811-2819.

[11]. Index Mundi (n.d.).Bangladesh GDP - composition by sector, retrieve from <http://www.indexmundi.com/bangladesh/gdp_composition_by_sector.html>, Access date December 7, 2016.

[12]. Kavoussi RM (1984) Export expansion and economic growth. J Dev Econ 14:241-250

[13]. Michaely M (1977) Exports and growth: an empirical investigation. J Dev Econ 4:49-53

[14]. Tahir, M., Khan, I., \& Shah, A. M. (2015). Foreign Remittances, Foreign Direct Investment, Foreign Imports and Economic Growth in Pakistan: A Time Series Analysis. Arab Economic and Business Journal, 10(2), 82-89.

[15]. Tyler WG (1981) Growth and export expansion in developing countries. J Dev Econ 9:121-130

[16]. Van den Bergh, J. C. (2009). The GDP paradox. Journal of Economic Psychology, 30(2), 117-135.

[17]. World Bank (2013). Population density (people per sq. km of land area) retrieve from <http://statisticstimes.com/population/countries-by-population-density.php>, Access date December 7, 2016

[18]. World Bank (2015). WB Update Says 10 Countries Move Up in Income Bracket retrieve from <http://www.worldbank.org/en/news/press-release/2015/07/01/new-world-bank-update-shows-bangladesh-kenya-myanmar-andtajikistan-as-middle-income-while-south-sudan-falls-back-to-low-income> accessed on December 6, 2016.

[19]. Zaheer, R., Khattak, S. W., Asha, H., Zaib, K., (2014). Impact of exports imports on GDP growth rate, Pakistan time series data from 2010-2014, 2(7), 29-34 